\title{
European Union Regulations of Corporate Reporting As a Response to the Evolution of Business Activity Conditions
}

\author{
Ryszard Kamiński ${ }^{1}$ \\ ${ }^{1}$ Adam Mickiewicz University in Poznań, Poland. \\ Correspondence: Ryszard Kamiński, 61-714 Poznań, Al. Niepodległości 53, Poland.
}

Received: September 28, 2015

Accepted: October 31, 2015

Available online: November 2, 2015

doi:10.11114/afa.v2i1.1185

URL: http://dx.doi.org/10.11114/afa.v2i1.1185

\begin{abstract}
The characteristic feature of today's business communication is an interaction between enterprises and their external economic and social environment, which in turn demands from enterprises to develop a new approach to the scope and form of business reporting system. Activities in this area have been taken in the European Union. They were intensified after the emergence of the economic crisis in 2007. The European Union adopted new regulations on corporate reporting. Their goal was to increase business transparency and as a result - increase the efficiency of the economy. This article aims to present the new system of financial and non-financial reporting in the European Union and to evaluate these systems, focusing in particular, on the recent developments that have occurred in consequence of the changing conditions and operating environment of undertakings.
\end{abstract}

Keywords: financial statement, auditing, supervision, reporting standards, EU directives.

\section{Introduction}

The economic crisis that began in 2007, which affected most economies of the member countries of the European Union, contributed to the intensification of work on the modern reporting concepts. The content that was the subject of traditionally defined reporting is presented in a new way. At the same time the scope of the report has extended to cover new areas. Some of the concepts are similar, others are distinctly different, some concepts penetrate each other and use ideas from others. The observed search for new reporting concepts has also inspired the writing of this article.

The aim of the paper is to present and evaluate the system of reporting in European Union, as well as changes in this area which are taking place under the influence of the evolution of the conditions for businesses.

The aim of the paper determined the content and sequence of the main issues tackled with in the text. These include:

1. Characterising the international financial reporting concepts of European level.

2. Presenting the reporting on non-financial areas.

3. Presenting the supervision and control system of financial reporting.

The study included companies obliged to prepare financial statements in accordance to UE regulations. The regulations quoted in this article are in force as at 31 December 2014. The primary source material used in the work were the rules and standards (mandatory and optional) on companies reporting. The work methods that were used include descriptive analysis method and a comparative method.

\section{Regulations of the Financial Accounting}

The second half of the twentieth century has witnessed the beginning of the process of globalisation of business and the capital markets. It triggered the need for free and safe movement of capital, goods and services, technology and information between companies from all around the world. This security was conditioned by accurate and reliable information that need to be provided on the economic situation and the effects of the activities of companies operating in different countries. The instrument that enabled fulfillment of this condition was a harmonized accounting system at the international level.

The first organisation that undertook the harmoniszation of accounting was the European Economic Community (EEC), 
subsequently transformed into the European Union ${ }^{1}$. This organisation has taken a number of initiatives and activities towards the harmonisation of the regulation of accounting and financial reporting in the member states. To achieve this goal the EEC has adopted a number of directives on accounting, financial reporting and auditing of financial statements. In the case of financial reporting enterprises - the most important acts were the Fourth Directive of 25 July 1978. No. 78/660/EEC on the annual accounts of certain types of companies (Official Journal ECC, 1978) and the Seventh Directive of 13 June 1983. No. 83/349 /EEC on the consolidated financial statements (Official Journal ECC, 1983). Their introduction to the practice was not an easy process, because it was associated with the loss of freedom in the shaping of the law in a country being a member of the community. This determined the content of the directives. They took into account the cultural diversity, economic development and legal traditions.

In 2011, the European Commission has taken steps aimed at supporting entrepreneurship and social responsibility economy. According to the European Commission's - the Fourth and Seventh Directives did not provide sufficient transparency of financial reporting, or comparability of the EU Member States; at the same time, due to their complexity, these directives affected the increase in administrative obligations of companies as the company experienced a particularly severe in the SME sector. The effect was a new law on accounting - Directive of the European Parliament and of The Council 2013/34/EC of 26 June 2013 on the annual financial statements, consolidated financial statements and related reports of certain types of undertakings, amending Directive 2006/43/EC of The European Parliament and of The Council and repealing Council Directives 78/660/EEC and 83/349/EEC (Official Journal UE, 2013).

Directive 2013/34 / EU refers to companies with limited liability, and therefore it includes joint-stock companies, public limited companies, limited liability companies, limited joint-stock, partnerships and limited partnerships and companies with a similar legal form. The directive also applies to credit institutions and insurance companies. The Directive does not apply to non-commercial entities. Units that are subject to regulation by the Directive are divided according to the criterion scale to large, medium-sized, small-sized and micro enterprises.

The main objective of the new Directive is to harmonisze financial reporting principles, and thus increase the clarity and comparability of financial statements. It is assumed that it will improve the functioning of the market and improve the protection of the interests of users of financial statements by providing them the necessary information. Another important objective of the Directive 2013/34 / EU is to reduce and simplify the administrative responsibilities, mainly in small and medium-sized companies. This objective will be achieved by giving member states the right to exempt small and medium sized companies from obligations set out in the Directives. It was assumed that small companies operating in the EU should be treated in the same way and is not appropriate for member states to impose additional national responsibilities on those units. The financial reporting for medium and large companies should be more comparable across the European Union, but at the same time in each country there can be certain additional reporting obligations for these units.

Directive 2013/34 / EU refers both to the individual financial statements and consolidated financial statements. It was formulated as a set of general principles for the preparation of financial statements. According to it - the financial statements show, in a true and fair view, the economic and financial situation of a company and its financial results. This major principle means that it is possible for a company to withdraw from other rules formulated in the Directive if it does not improve its fair and true picture.

Under the new Directive, financial statements include the balance sheet, the profit and loss account and the notes. This applies to both large, medium-sized and small units. The Directive provides, however, that the Member States may extend financial statements with additional elements (ie. cash flow statement) for medium-sized and large units. However, in the case of small companies - member states were allowed to reduce the reporting requirements of these units by:

- preparing the balance sheet and the statement of profit and loss (under certain conditions) in an abbreviated form (see. Art. 14), reducing the notes to the financial statements (see. Art. 16 and 17);

- not to impose a statutory requirement to audit the financial statements;

- exemption of small groups of companies from the obligation to prepare consolidated financial statements.

In addition, it is assumed that in the case of micro-entities - both the balance sheet and profit and loss report - can be

\footnotetext{
1 An organization that has the greatest achievements in the creation and promotion of accounting standards in the world is the International Accounting Standards Board, IASB (formerly: International Accounting Standards Committee, IASC). The purpose of this organization is to standardize the rules of accounting and reporting used by businesses and other organizations on a global scale. It was assumed that this objective will be achieved by formulating and publishing understandable and workable in practice, global accounting standards. It was assumed that the financial reporting will be of high quality, transparent and comparable.
} 
prepared in abbreviated form.

Directive established two models of the balance sheet. In accordance with Article 10 of the Directive, Annexes No. III specified the horizontal arrangement of the balance sheet, and Annex IV the vertical layout. In accordance with Art. 13, the Directive also establishes two patterns of profit and loss statements; by nature in Annex V, and by function of expense pattern in Annex VI. These patterns are the minimum set of information contained in the report. They can be particularized, however, the order and extent of the information provided in the financial statements contain at least the information set out in the Directive.

Both the annual accounts and consolidated accounts should be audited by the auditor; small units, may be exempted from this obligation, however this is dependent on the decision of the Member State.

As already mentioned, the aim of the Directive is to reduce the administrative costs of companies, through the introduction of a number of exemptions and simplification in particular in the case of micro entities and small companies. However, this rule does not apply to public interest entities. The Directive prohibits the use of any simplifications by such entities. Public interest entities are:

- both governed by the law of a Member State and listed on a regulated market,

- credit institutions in the EU, irrespective of whether listed or not,

- insurance undertakings in the EU, regardless of whether they are listed or not and regardless of whether they are life, non-life, insurance or reinsurance undertakings,

- entities designated by Member States as public-interest entities, for instance undertakings that are of significant public relevance because of the nature of their business, their size or number of employees.

At the same time Directive imposed on listed companies obligation of to preparing a statement on corporate governance (Art. 20). In such statement, the companies will be required to disclose information regarding their diversity policy as to cast their of administrative, management and supervisory bodies.

Directive 2013/34 / EU on accounting organises the existing EU regulations devoted to the financial reporting of companies, mainly capital. It imposes on Member States an obligation to apply certain simplifications for small companies, but does not introduce many new changes to the substance, nor does it contribute to a significant increase comparability of reporting companies from different EU countries. The content of the Directive is the result of a compromise between Member States used in the accounting models - Anglo-Saxon and continental. It has been achieved through the introduction of a number of possible options to resolve the same problem. The use of equivalent alternatives, however, requires to complete the financial statements with relevant explanations and notes. The Directive contains a number of options, based on which the Member States will determine which obligations will apply to certain undertakings. However, in the future the scope of the reporting requirements, particularly for small companies will be reduced. The final direction and scope of the changes will largely depend on the decision of the Member States.

Member States are required to implement the regulations of new Directive into their legislation within two years, at the latest by 20 July 2015. However, the final regulations of the new Directive allows Member States to postpone the deadline for the application of the new rules. If a Member State decides to take advantage of this opportunity, the new rules will apply to financial statements for fiscal years beginning on January 2016 or later.

\section{Non-financial information}

The contemporary reporting model is evolving to the growing importance of accurate information on non-financial activities of companies. Among them, the greatest attention is focused on the aspects of Corporate Social Responsibility (CSR). Corporate social responsibility is a multifaceted area of theoretical reflection and practical activities for a number of disciplines, including accounting and reporting. The idea of corporate social responsibility is a voluntary activity taken by companies and focused on the needs of different groups of stakeholders and respect for the natural environment. These activities go beyond the minimum legal requirements but are nevertheless considered by companies in their strategy. Due to the lack of clear, legal definition of corporate social responsibility used in practice, a CSR report depends on the expectations of key stakeholders, the tradition of the company, its ideology, as well as the characteristic values for the society, its culture and ethical standards.

The European Union's policy in the field of corporate social responsibility has been practically reflected in the published in 2001, the European Commission's "Green Paper: Promoting framework for Corporate Social Responsibility" (COM, 2001). The document states that socially responsible business is one when "companies

during the European Summit in Lisbon. The reason for these actions was to create the European Union, as the most competitive area

${ }^{2}$ Green Paper on CSR was preceded by the publication of the social and economic plan - called Lisbon Strategy, founded in 2000 in the world, and thus, the economy focused on continuous and dynamic development. 
voluntarily take into account social and environmental aspects of their business activities and in relations with its stakeholders. "Subject to regulation by the EC Green Paper contains internal and external CSR issues. Among the internal issues are: human resources management, health and safety, the ability to adapt to changes as well as environmental management. The issues of an external environment regulated by the Green Paper are: cooperation with the local community and business partners, human rights and environmental problems.

Work undertaken in the development of the Green Paper was continued, and, as a result, a new document was issued on - the strategy of implementation and dissemination of corporate social responsibility, the so-called White Paper (COM, 2002), addressed to the European institutions, member states, social partners, business organisations, consumers and enterprises. The White Paper complemented the contents of the Green Paper in those areas of activity which concerned solving of problems related to CSR. These are: education, exchange of experience and good practices, the development of corporate social responsibility instruments, launching the European Multistakeholder Forum on CSR (Corporatejustice, 2004) and the inclusion of CSR issues in all EU policies (employment, economic, environmental, consumer, external, public administration).

Environmental information and information relating to social activities, or other non-financial aspects of companies operating in the EU could, of course, have already been disclosed prior to the adoption of the Green and White Paper, even on the basis of the Fourth Directive on the annual financial statements. However, this possibility was rarely used. Therefore, the European Union adopted a new strategy for 2011-2014 on corporate social responsibility in order to support the development and coordination of Member States' policies on CSR (COM, 2011). Following this, in 2011, the European Commission (EC) issued a statement in which it introduced a new definition of corporate social responsibility ${ }^{3}$ and formulated a plan for the development of good practices in the area of CSR in the Member States "European Commission Communication on CSR 2011: Implementation table" (ec.europa.eu, 2001). One of the objectives of the adopted plan was to improve the quality of reporting of environmental and social issues. Valuable guidelines for reporting on CSR have been recognized standards United Nations Global Compact, the OECD Guidelines, ISO 26000 and the Tripartite Declaration of the International Labour Organization.

In 2014 the Commission has conducted a review of activities of the last years, to help prepare the next EU policy framework on CSR. This review process started with a comprehensive public consultation, which was open from April until August 2014. This consultation were part of the review of actions under the CSR Strategy. The results of the consultation will be used for the development of the successor strategy, to run from 2015 to 2020. They were presented to the CSR Multi-Stakeholder Forum, on February 2015, with a view to a well-informed discussion on the future direction of the European Commission's CSR actions in that period (DG Enterprise \& Industry, 2014, p. 3,4).

Another important step in the subject of non-financial information reporting was the adoption (already discussed) the Directive 2013/34 / EU, which is assumed to disclose information on environmental issues, social and employment issues, including the protection of human rights, anti-fraud and corruption, respecting the principle of diversity management. Directive 2013/34 / EU provides the obligation of reporting non-financial information related to corporate social responsibility by large public interest companies, having more than 500 employees, in the form chosen by the company, ie. either in the annual financial report or in a separate report.

This principle of disclosure of non-financial information nevertheless leaves companies freedom to design and implement CSR strategy - it also gives them a certain degree of freedom in determining the information to be disclosed. CSR reports are to be drawn with respect for the principle of "comply or explain", that means the need to explain the reasons for non-disclosure of certain information. The above rules apply only to entities considered to be public interest entities, ie. companies listed on the stock exchanges, insurers, banks and companies recognised by the EU Member States as socially important because of the nature of their business. There are about 6,000 companies of that kind (Banking and Finance, 2014).

Directive 2013/34/EU as regards disclosure of non-financial and diversity information by certain large undertakings and groups was amended by the Directive 2014/95/EU (Official Journal UE, L 330/1, 2013). According to new Directive a non-financial report, or "statement", should contain information relating to, as a minimum:

environmental matters (eg health and safety, use of renewable and/or non-renewable energy, greenhouse gas emissions, water use and air pollution),

social and employee-related matters (eg gender equality, implementation of funda-mental conventions of the International Labour Organization, working conditions, social dialogue, respect for the right of workers to be informed

\footnotetext{
3 The Commission defined CSR as "the responsibility of enterprises for their impacts on society", which is consistent with international instruments (OECD Guidelines for Multinational Enterprises, ISO 26000 and the UN Guiding Principles on Business and Human Rights), (DG Enterprise \& Industry, 2014, p. 5.).
} 
and consulted, respect for trade union rights, health and safety at work and the dialogue with local communities, and/or the actions taken to ensure the protection and the development of those communities), respect for human rights (eg information on the prevention of human rights abuses), anti-corruption and bribery matters (eg information on instruments in place to fight corruption and bribery).

Such statement should include a description of the policies, outcomes and risks related to those matters and should be included in the management report of the undertaking concerned. The non-financial statement should also include information on the due diligence processes implemented by the undertaking, also regarding, where relevant and proportionate, its supply and subcontracting chains, in order to identify, prevent and mitigate existing and potential adverse impacts.

Today stakeholders expect much more detailed information on the key areas of the company's business and operations, including information about the future. Therefore for those subjects with the environment apart from classical understanding of financial reporting are also important reports and projections for future non-financial areas. Companies that want to be socially responsible should incorporate environmental and social issues in their objective reporting. It is necessary, therefore, the use of the commonly accepted methods of measurement and presentation of the impact of businesses on the environment. Various organisations present a different approach to this. In UE, in most cases, the reporting of CSR has not yet reached the quality used for other types of reporting. This weakness is related to inter alia the problem of measurement issues covered by CSR reporting ${ }^{4}$. Thus, the ratios calculated on the basis of these measurements - cause doubt about their credibility. This means that the assessment of CSR activities can be ambiguous, especially in the case of the use of these ratios for comparison. Hence, the idea of verification of corporate social responsibility reports by independent, specialised auditors.

\section{The supervisory and control system}

Assuring the accuracy and reliability of the information presented in the statements of companies is achieved by a formalised system of supervision of financial reporting and control of accounting. The most important element of this is the examination of the financial statements by an independent auditor and formulating an independent auditor's report. The conclusion of the examination is opinion-forming, thus increasing the reliability of the published financial statements. Practice has shown, however, that is not so in every case. Accounting scandals of the early twenty-first century undermined the confidence in the fairness of the financial statements of companies, as well as auditors, whose work did not always meet the expectations of quality and objectivity.

The answer to these negative phenomena was taken by European Union - special projects aimed at improving the quality of financial reporting. An inspiration for the EU was American model of the Sarbanes-Oxley Act (SOX) of 2002 and activity of the US Public Company Accounting Oversight Board (PCAOB). The first important step was the adoption of Directive 2006/43/EC (Official Journal UE, 2006), which replaced Eighth Council Directive 84/253/EEC of 1984 (Official Journal EEC, 1984) and amended Fourth and Seventh EEC Directive. The solutions adopted in the Directive 2006/43/EC are the result of a long discussion on the shape of the new rules governing the external audit. As a result of this discussion, public companies were not required to incur excessive costs of auditing which might exceed the potential benefits of the audit. A strong financial and accounting lobby in the European Union had undoubtedly a large impact on the provisions of Directive 2006/43/ EC, which was, seeking to reduce the cost of the audit, not having, however, adequate counterweight from other pressure groups that defended the interests of investors and other users of financial statements.

The Directive imposed an obligation on each Member State to organize an effective system of public oversight for auditors and audit firms. The system of public oversight has a very broad range of responsibilities including (see Art. 32 (4) Directive 2006/43/EC):

- the approval and registration of statutory auditors and audit firms,

- the adoption of standards on professional ethics, internal quality control of audit forms and auditing,

- continuing education, quality assurance,

- investigative and disciplinary systems.

Among other duties that the European Council imposed on Member States is collaboration with one another's relevant organs that exercise oversight for statutory auditors and audit firms, known as home country control, the idea being that a supervisory organ of a Member State in which an audit firm has been registered is ultimately and fully responsible for its

\footnotetext{
${ }^{4}$ It is difficult to measure of the company's reputation, satisfaction of employees and customers or affect to the quality of local communities life. So far, only in the case of standards for environmental protection have been developed methodologically correct and understandable measurement tools and methods of presentation.
} 
oversight, while a firm so supervised can operate and provide services within the whole territory of the European Union. The same Directive also regulates the procedures of information exchange between organs responsible for public oversight for statutory auditors and audit firms in Member States in the area of investigation and explanation. What is more, pursuant to its provisions, Member States are obliged to collaborate with third countries and their relevant institutions, such as e.g. the US Public Company Accounting Oversight Board and in compliance with the home country control principle.

Another noteworthy principle implemented by Directive 2006/43/EC is independence of a statutory auditor and an audit firm of the appointing company. This principle is to be safeguarded by the annual statement made by statutory auditors to the Audit Commission confirming their independence. Also each audited company is obligated to change its auditors every seven years. The auditors are also required to disclose information to the committees about other services they provide to customers. The Directive did not expressly prohibit auditors and audit firms from providing, at the same time, the same customer with audit services and other services. According to Article 22 (2) of the Directive, such services may be prohibited if there is any direct or indirect business relationship between the auditor, audit firm or network firms and the audited entity.

The Directive also required all statutory examinations to be performed in compliance with international auditing standards provided, however, that each standard concerned has been approved by the European Commission and has been incorporated in European law (Article 26).

Shortly after the publication of Directive 2006/43/EC, a debate started on whether the regulatory framework needed further improvements, in particular after the financial crisis started. It was concluded that the regulatory framework was inadequate to appropriately address the financial crisis challenges. In 2014 the European Union reformed the regulatory framework of statutory audits in Directive 2014/56/EC (Official Journal EU, L 158/196, 2014) and Regulation (EU) No. 537/2014 (Official Journal EU, L 158/77, 2014). The most significant changes introduced by these regulations include:

- the introduction of mandatory rotation of audit firms doing an audit of public interest entities,

- the prohibition on providing certain services to the audited entity of public interest,

- imposing a limit of remuneration for services other than auditing rendered to the audited entity of public interest,

- strengthening the role of the audit committee of public interest entity - by increasing its participation in the selection of the audit firm and in the process of auditing the financial statements of public interest entity,

- extending the scope of the information provided in the opinion of the audit,

- the introduction of an additional obligation to prepare an audit report for the audit committee of public interest entities,

- formulation of minimum requirements for the organisation's rules of audit firms,

- significant narrowing of the tasks of the public supervision body that will be delegated to a professional association of auditors.

An important part of the new legislation addresses the composition and responsibilities of the audit committee of public-interest entities. Directive 2014/56/EC strengthened the composition requirements but built in more flexibility regarding the competence of the committee members. The audit committee as a subcommittee of the (supervisory) board should consist of several non-executive directors and the majority of the members must be independent. Moreover, Directive 2006/43/EC ordered that at least one independent board member was competent in accounting and/or auditing. This Directive disentangled independence from competence in accounting/auditing. Another innovation of Directive 2014/56/EC regarding the composition of the audit committee relates to the chairman of the committee. The chairman must be independent of the audited entity. Furthermore, the Member States can opt to exempt the members from the independence requirement when all the members of the audit committee are selected from the (supervisory) board of the entity.

It should be added that the audit issues are also regulated by the Directive 2013/34/EU. As already mentioned Directive 2013/34/UE aims at simplifying the accounting requirements for small companies and improves the clarity and comparability of companies' financial statements within the European Union. According to Article 34 - Auditing General Requirement - there is a requirement for the audit of medium-sized and large companies only. It is clear that Member States can nevertheless decide whether require an audit from small companies or not.

This brief review of the legislation on the audit confirms that the accent is placed on control of the reporting units of medium and large scale; first of all public-interest entities. The new European legal framework of audit focuses on the way of action committees of public-interest entities. The role and importance of this committee is considered to be pivotal. Therefore audit committees are obligated to monitor the work and independence of the auditor. 
Some analysts have certain doubts whether all the new measures are equally advantageous for reaching the goal of an effective statutory audit. They say that the responsibilities of the audit committee as an "advisory" subcommittee of the (supervisory) board which remains the ultimate responsible corporate organ is stretched to the extreme, and will consequently significantly raise the costs. Moreover, they argue that some of the policy elements of the new audit framework, such as better audits in a more competitive market, will not reach their goal. The heavily regulated audit market with low margins, significant liability risks and high insurance premiums could become unattractive and peripheral to some audit firms which might refocus their strategic investments in more lucrative other (non- audit) services (Van der Elst, 2014, p. 19).

Important part of the surveillance system of companies reports is also a corporate governance. During the process of developing and promoting the principles of corporate governance - much emphasis has been, placed on companies' control system of accounting and financial reporting. The European Union have a significant contribution to the development of corporate governance standards. The background to the debate in the European Union on corporate governance began with the report of the High Level Group of Company Law Experts in 2002 (ec.europa.eu., 2002). This report, entitled "A Modern Regulatory Framework for Company Law in Europe" focused on corporate governance and the modernisation of company law. This report concluded that the EU should not attempt to develop a pan-European code but rather consider "a certain coordination" of corporate governance codes to encourage further convergence. This convergence should focus on both, the reducing of barriers to cross-border voting by shareholders as well as the reduction of barriers to information that affect shareholders' ability to evaluate the governance of companies.

In 2014, the European Commission announced a new proposal to improve corporate governance within the European Union - "Commission Recommendation of 9 April 2014 on the quality of corporate governance reporting ('comply or explain')" (Official Journal EU, L 109/43, 2014). The proposals aim to improve corporate governance reporting by listed companies. The purpose of this Recommendation is to provide guidance to Member States and their government bodies responsible for national corporate governance codes, companies and other parties concerned. The guidance aims to improve the overall quality of corporate governance statements published by companies in accordance with Article 20 of Directive 2013/34/EU and, specifically, the quality of explanations provided by companies in the case of departure from the recommendations of the relevant corporate governance code.

The supervision and control of the preparation of a financial report can have a substantial role for the improvement of the quality of financial reporting and increase in the investors' faith in company's financial reports. This is particularly so since financial reporting is a true indicator of a company's operating activities and as such it should provide true information to shareholders about the company's state of affairs, on the basis of which the investors could make decisions whether to invest in a company or not. The degree to which corporations observe basic principles of good corporate governance is an increasingly important factor for investment decisions. Adherence to good corporate governance practices can help to improve the confidence of investors, reduce the cost of capital, underpin the good functioning of markets, and ultimately induce more stable of economic developing.

\section{Conclusions}

Trends in the development of reporting outlined by the EU are showing a right direction and should be given a credit. Drafts of new regulations and the recently adopted ones take into account the current trends in the development of enterprises and the current needs of local communities and state governments. However, further successful development of a reporting system requires cooperation of many actors involved in the creation of this system (EU Commission, member states of EU, professional organizations).

However, as of today - reporting systems in EU does not fully satisfy the demands of current information users. There are many users of financial reports who do not only need the financial information, but are interested in the non-financial details, too. For others, it is not only the quantitative, but also the qualitative information that counts more, or perhaps rather than total information, they only need partial, or selected data. The information offered by the current financial reports mainly offers the historical data. This is an obvious weakness of these reports. Another important shortcoming is that basing on the reports received today very often stakeholders cannot reasonably predict the future development of an enterprise. Therefore, in the future, financial reports should disclose information which may help to forecast the future value of an enterprise in as much detail as possible (company's experience, its business model, technologies, intellectual property etc.). The future financial report system should take into account the reporting information the users actually demand, and provide a series of financial information needed in the modern market economy. This is especially important for companies operating in international markets, where due to differences existing between the national systems of accounting and financial reporting, readers of reports from different countries must be aware of these differences and be able to take them into account in the assessment of the financial situation of their company. It must be remembered that the desire to increase the informational value of the financial statements must be confronted with the requirement to limit costs of preparation of financial statements and interpretation of the 
reported information. Reducing the cost of preparing the report is particularly important for companies from the SMEs sector.

\section{References}

Banking and Finance. (2014). Non-Financial Reporting. Retrieved from http://ec.europa.eu/finance/ accounting/non-financial_reporting/index_en.htm

Commission of the European Communities. (2001). Green Paper. Promoting a European framework for Corporate Social Responsibility. Brussels. COM(2001) 366 final.

Commission of the European Communities. (2002). Corporate Social Responsibility: A business contribution to Sustainable Development. Brussels. COM(2002) 347 final.

European Commission. (2011). European Commission Communication on CSR 2011: Implementation table, Brussels. http://ec.europa.eu/enterprise/policies/sustainable-business/files/doc/ csractionstimeline121213 webversion_en.pdf

European Commission. (2014, November). The Corporate Social Responsibility Strategy of the European Commission: Results of the Public Consultation. DG Enterprise \& Industry.

European Multistakeholders Forum on CSR. (2004). Final results \& recommendations. Final report, Retrieved from http://www.corporatejustice.org/IMG/pdf/CSR_20Forum_20final_20report.pdf

Official Journal L 126. (1984, May 12). Eighth Council Directive 84/253/EEC of 10 April 1984 based on Article 54(3)(g) of the Treaty on the approval of persons responsible for carrying out the statutory audits of accounting documents.

Official Journal L 157. (2006, June 9). Directive 2006/43/EC of The European Parliament and of The Council of 17 May 2006 on statutory audits of annual accounts and consolidated accounts, amending Council Directives 78/660/EEC and 83/349/EEC and repealing Council Directive 84/253/EEC.

Official Journal L 193. (1983, July 18). Seventh Council Directive 83/349/EEC of 13 June 1983 based on Article, $54(3)(g)$ of the Treaty on consolidated accounts.

Official Journal L 222. (1978, August 14). Fourth Council Directive 78/660/EEC of 25 July 1978 based on Article, 54(3) $(\mathrm{g})$ of the Treaty on the annual accounts of certain types of companies.

Official Journal of the European Union L 109/43. (2014). Commission Recommendation of 9 April 2014 on the quality of corporate governance reporting ('comply or explain'), (2014/208/EU).

Official Journal of the European Union L 182/19. (2013). Directive 2013/34/EU of The European Parliament and of The Council of 26 June 2013 on the annual financial statements, consolidated financial statements and related reports of certain types of undertakings, amending Directive 2006/43/EC of the European Parliament and of the Council and repealing Council Directives 78/660/EEC and 83/349/EEC.

Official Journal of the European Union, L 158/196. (2014). Directive 2014/56/EU of The European Parliament and of the Council of 16 April 2014 amending Directive 2006/43/EC on statutory audits of annual accounts and consolidated accounts.

Official Journal of the European Union, L 158/77. (2014). Regulation (EU) No 537/2014 of The European Parliament and of The Council of 16 April 2014 on specific requirements regarding statutory audit of public-interest entities and repealing Commission Decision 2005/909/EC.

Official Journal of the European Union, L 330/1. (2014). Directive 2014/95/EU of The European Parliament and of the Council of 22 October 2014 amending Directive 2013/34/EU as regards disclosure of non-financial and diversity information by certain large undertakings and groups.

The Council, The European Economic and Social Committee and The Committee of The Regions. (2011). A renewed EU strategy 2011-14 for Corporate Social Responsibility, Communication from the Commission to the European Parliament. Brussels. COM(2011) 681 final.

The High Level Group of Company Law Experts. (2002, November 4). A Modern Regulatory Framework for Company Law in Europe. Brussels. Retrieved from http://ec.europa.eu/internal_market/company/docs/modern/report_en.pdf

Van der Elst, C. (2014 December). Audit Committees of Public Interest Entities in Europe, ECGI Working Paper Series in Law.

\section{(cc) $\mathrm{BY}$}

This work is licensed under a Creative Commons Attribution 3.0 License. 